\title{
ADAPTABILITY STRATEGIES OF LEARNERS AGAINST COVID-19 UNCERTAINTY
}

\author{
Lopez $\mathrm{M}^{1,2^{*}}$, Segura-Azuara NDA ${ }^{1}$, Elizondo-Leal $\mathrm{JA}^{1}$ and Eraña- \\ Rojas IE ${ }^{1}$ \\ ${ }^{I}$ Tecnologico de Monterrey, Escuela de Medicina y Ciencias de la Salud, México \\ ${ }^{2}$ Writing Lab, Institute for the Future of Education, Tecnologico de Monterrey, Monterrey, \\ México
}

\begin{abstract}
New infectious diseases, especially one of the magnitudes of COVID-19, leads to complex situations for individuals and communities alike. Particularly in higher education, learners faced a surrealist world in which education shifted abruptly to an online setting because of the virus. Regardless of their field of study, they had to apply coping strategies to adapt and incorporate new values, beliefs, and perspectives into a new learning environment. Universities must foster educational opportunities to train learners on these capacities to prepare professionals for their success in their profession. This study's objective was to assess these adaptability strategies that higher-education learners had to tackle the uncertainty of the coronavirus pandemic. A quantitative approach was considered with a descriptive and cross-sectional design. The convenience sample consisted of 34 learners in the final year of their medical program. As an instrument, an adaptation of the Proactive Coping Inventory was used with a 5-level Likert scale where 1 stands for total disagreement and 5 with total agreement. According to the results, students use more than one strategy to cope with difficult situations. The mean obtained in the control strategy was 3.98 , curiosity 3.18 , confidence 3.02 , and concern was 2.97 . The ANOVA test showed that there is no significant difference in the dimensions ( $\mathrm{p}$-value of 0.062). These results indicate that students had the intellectual curiosity to propose new personal and professional development goals and monitor the scope of those through selfregulation. Institutions need to learn from what they implemented amid the pandemic and incorporate best practices for the new normality ahead.
\end{abstract}

Keywords: educational innovation, higher education, professional education, medical education, coping strategies, pandemic adaptations

\section{Introduction}

Globalization, the unpredictability of economic models, and epidemiological transitions make the learning and working environment a horizon full of uncertainty (Olivares et al., 2019). At the date of the declaration of COVID-19 as a pandemic, there were more than 118,000 cases in 114 countries, and nearly 4,000 people had lost their lives (WHO, 2020). The appearance of this new infectious disease of this magnitude leads to a complex situation (Llisterri Caro, 2020; Palacios et al., 2020; Trilla, 2020). The declaration as a health emergency entails extraordinary measures such as the immediate suspension of non-essential activities in the public, private, and social sectors to mitigate the spread of the virus (Peña-Otero et al., 2020). 
Different educational levels, public and private, had an abrupt transformation to an online educational offer as a fast response to protect students and guarantee at least academic continuity (Peña-Martínez \& Lopez, 2021; Poh-Sun \& Sandars, 2020); therefore, their focus was on content distribution through the use of learning management systems (Valdez-García et al., 2020). However, several authors have argued about the effect of this reaction and how it led to a strong reaction among students who experienced high levels of anxiety about their health, the lives of their loved ones, and their professional futures (Baloran, 2020; Nieto \& Lopez, 2020; Rose, 2020). Educational institutions have developed innovative proposals to engage with students during these challenging times and acting as a true community that cares for its members (Eraña-Rojas \& Lopez, 2021; Méndez Reguera \& Lopez, 2020).

In higher education, universities are required to prepare professionals in technical competence and generic skills; however, regardless of their specialty, a vital component for their success is developing adaptation strategies (Guzman \& Choi, 2013). For some authors, such as Pidgeon and Pickett (2017), having these abilities is a positive predictor for successful adjustment to university and retention outcomes, as students can bounce back from adversity. Other authors, such as Schiller et al. (2017), have linked analyzed the shift of strategies that students employ as they progress in their program. As students engage closely with professional practice, they seem to use more emotional strategies and decrease the use of active coping strategies.

Although facing uncertainty is a naturally occurring problem that trainees have during their practice, lacking these abilities may cause such distress that it endangers their good judgment (Kim \& Lee, 2018). Some authors conceptualize it as a capacity, process, and result, reflecting the positive interactions between individuals and their environments for personal growth, defining it as resilience (Mansfield et al., 2016). Other studies define it as coping, referring to the cognitive and behavioral processes developed to handle specific demands that surpass the individual's resources (Folkman \& Lazarus, 1980; Folkman et al., 1986).

Strategies for coping are tools that an individual uses at a specific time to face or cope with an event or situation that is adverse. According to the situation's characteristics, an individual may have different behaviors or strategies for the same situation or a combination (Al-Sowygh, 2013). For Parker et al. (2017), coping responses are reactions to specific stressful situations that may vary. Fernández-Abascal et al. (1997) describe them as highly changing and related to the factor or situation that caused it. The factors of support, denial, problem-solving, and hope can explain confrontation strategies (Steinhardt \& Dolbier, 2008). These strategies, desperately needed in the pandemic, allow the professional to have personal resources to face uncertainty (Cullen et al., 2014). 
Four adaptability strategies activate the use of technical competence and generic skills: concern, curiosity, control, and confidence (Kivunja, 2014; Olivares et al., 2019). Concern refers to thinking and preparing for the future; frequently, it has a negative connotation associated with restlessness (Cullen et al., 2014). Curiosity is related to exploring and actively looking for opportunities to succeed (Olivares et al., 2019). Control is the autonomy and initiative for decision-making, based on the individual's internal attributes (Guzman \& Choi, 2013). Confidence is the belief and certainty that the defined goals and objectives will be achieved (Cullen et al., 2014). Attributes related to student wellbeing and achievements. Figure 1 represents the interaction between these strategies and activation of technical and generic skills against the COVID-19 uncertainty.

This study's objective was to assess these adaptability strategies that higher-education learners had to tackle the uncertainty of the COVID-19 pandemic.

\section{Methods}

A quantitative study was carried out with a descriptive and cross-sectional design (Hernández et al., 2006). The convenience sample consisted of 34 learners in the final year of their medical program. They participate in a not-for-profit private university in Latin America that has declared a challengebased learning program (Olivares et al., 2018).

As an instrument, an adaptation of the Proactive Coping Inventory was used (Greenglass, 1999). This instrument has been thoroughly analyzed, and several authors have discussed its validity in similar contexts (Dwivedi \& Rastogi, 2017; Drummond \& Brough, 2016; Jauregui et al., 2016; Roesch et al., 2009). A 5-level Likert scale was used where 1 stands for total disagreement and 5 total agreement. The analysis considers descriptive statistics to assess trends in items and analysis of variance, ANOVA to compare results between strategies. To assess the internal consistency of the instrument, Cronbach's alpha was calculated. This coefficient ranges from 0 to 1 , and values above 0.7 represent appropriate consistency in psychometric scales (Vogt, 2007). The Minitab 18 package was used as software.

\section{Results}

According to the results, students use more than one strategy to cope with difficult situations. The highest mean was obtained in the control strategy with 3.98. The second highest was curiosity with a mean of 3.18. Then the confidence strategy with a mean of 3.02. The lowest score was the concern strategy with a mean of 2.97. However, the ANOVA test showed that there is no significant difference in the dimensions (p-value of 0.062). These results are presented in detail in Table 1. 
Table 1: Students' perception of their adaptation strategies

\begin{tabular}{|c|c|c|c|}
\hline Strategy & Item & Mean & $\begin{array}{l}\text { Standard } \\
\text { deviation }\end{array}$ \\
\hline \multirow[t]{2}{*}{ Concern } & $\begin{array}{l}\text { 1. I often see myself failing so I don't get my hopes up too } \\
\text { high.* }\end{array}$ & 3.00 & 1.14 \\
\hline & $\begin{array}{l}\text { 2. When I have a problem, I usually see myself in a no-win } \\
\text { situation.* }\end{array}$ & 2.94 & 0.94 \\
\hline \multirow[t]{3}{*}{ Curiosity } & $\begin{array}{l}\text { 3. After attaining a goal, I look for another, more challenging } \\
\text { one. }\end{array}$ & 3.29 & 1.10 \\
\hline & 4. I like challenges and beating the odds. & 2.97 & 1.09 \\
\hline & 5. I try to pinpoint what I need to succeed. & 3.24 & 0.89 \\
\hline \multirow[t]{5}{*}{ Control } & 6. I am a "take charge" person. & 3.94 & 0.92 \\
\hline & $\begin{array}{l}\text { 7. If someone tells me I can't do something, you can be sure I } \\
\text { will do it. }\end{array}$ & 2.27 & 1.10 \\
\hline & 8. I try to let things work out on their own.* & 2.29 & 0.95 \\
\hline & $\begin{array}{l}\text { 9. When I experience a problem, I take the initiative in } \\
\text { resolving it. }\end{array}$ & 3.41 & 0.90 \\
\hline & 10. I turn obstacles into positive experiences. & 3.09 & 0.92 \\
\hline \multirow[t]{4}{*}{ Confidence } & $\begin{array}{l}\text { 11. I always try to find a way to work around obstacles; } \\
\text { nothing really stops me. }\end{array}$ & 3.32 & 0.76 \\
\hline & 12. I visualize my dreams and try to achieve them. & 3.27 & 1.01 \\
\hline & $\begin{array}{l}\text { 13. Despite numerous setbacks, I usually succeed in getting } \\
\text { what I want. }\end{array}$ & 2.74 & 0.93 \\
\hline & 14. When I apply for a position, I imagine myself filling it. & 2.77 & 1.21 \\
\hline
\end{tabular}

\section{* Items written negatively}

The items with the most favorable response were " 6 . I consider myself a person who takes charge of the situation" with a mean of 3.94, "9. When I experience a problem, I take the initiative in resolving it" with 3.41 , and "11. I always try to find a way to work around obstacles; nothing really stops me" with 3.33. The least favorable responses were found in "7. If someone tells me that I cannot do something, you can be sure that I will do it" with a mean of 2.27 ", "8. I try to let things work out on their own" with 2.29 and "13. Despite numerous setbacks, I usually succeed in getting what I want" with 2.74 .

According to the results, the instrument has adequate internal consistency, as Cronbach's alpha coefficient was 0.82 which is considered acceptable for these scales (Vogt, 2007).

\section{Discussion}

According to the results, students apply different strategies. The strategy that ranked higher was the control one. This strategy refers to people that are doers that take the initiative on their own. The 
professionals who graduated had an extra challenge to incorporate into the workforce or apply to postgraduate programs if compared with the class that graduated the year before (Eraña-Rojas \& Lopez, 2021). The ongoing COVID-19 sanitary emergency, where they leave the safe space that the university has posed, demands the expeditious application of people with initiatives that turn obstacles into positive experiences. The students who have internalized these the most are the ones who can cope with uncertainty and propose alternatives where the community can thrive.

The second higher strategy was curiosity. Therefore, participants had the intellectual curiosity to propose new personal and professional development goals and monitor the scope of those through self-regulation. These resources are part of the constant search for answers and personal growth enablers of learning throughout life. Early on in their training, health professionals participate in clinical contexts where incremental autonomy is planned to care for patients and their families. In many contexts, these professionals also perform a one-year internship placement in a community setting, where they are no longer under a close monitoring program where faculty members participate. This sense of self-sufficiency to regulate, analyze and assess their performance prepares them to perform in fast-paced environments. It would be necessary for other professions to incorporate these experiences, even in a simulated or role-play situation where they could rehearse or reenact how they would perform.

The third-ranked strategy was curiosity. In fact, the results are consistent with those obtained in the study by Olivares et al. (2019), where students favored personal learning and curiosity to become independent and self-regulated professionals. These adaptation strategies tackle the uncertainty that the communities have been experimenting with the coronavirus pandemic. Making conscious efforts to regulate emotions, behaviors, and physical responses in new and creative ways will prepare them for an uncertain future (Jauregui, Herrero-Fernández \& Estévez, 2016). Although the situation itself is not modified, it is possible to incorporate strategies for students to perceive their future as hopeful for it to be likely to reduce the tension it produces on the person, although the situation remains unchanged.

The lowest score strategy was a concern that refers to the perception of being in a no-win situation where hopes should not be too high. These differ from that reported by Guzmán and Choi (2013), who showed a more favorable trend in the concern strategy because their sample belonged to students enrolled in a vocational orientation program that allocated spaces to reflect and plan their professional future.

The study's limitations were the sample size, which was limited, and that the participants were only for the health program. Further studies should incorporate a larger sample of participants, including graduating students from other health professions such as dentists, nutritionists, nurses, and other 
disciplines. An interesting approach would be to compare their approaches on how to face challenges in professional practice. An essential step for universities such as the one where this study was conducted would be to do a follow-up study to check how students handle the stress and loneliness of this pandemic.

\section{Conclusion}

The coping training that students receive is rarely part of the formal curriculum but instead grows within their professional culture. Traditionally, they try to master these skills through real-context experiences by observing their mentors and facing the challenge itself. Institutions need to learn from what they implemented amid the pandemic and incorporate best practices for the new normality ahead (Peña-Martínez \& Lopez, 2021). New curriculum designs must integrate the development of these skills early on in their training for them to internalize those values and attitudes. Fuelling individual personal growth, capitalizing on existing knowledge and skills, specific skills of lifelong learning, we can prepare students to tackle the uncertainty of challenges in a time of collective crisis.

\section{References}

Baloran, E.T. (2020). Knowledge, Attitudes, Anxiety, and Coping Strategies of Students during COVID-19 Pandemic. Journal of Loss and Trauma, 25(8), 635-642. https://doi.org/10.1080/15325024.2020.1769300

Cullen, K. L., Edwards, B. D., Casper, W. C., \& Gue, K. R. (2013). Employees' Adaptability and Perceptions of Change-Related Uncertainty: Implications for Perceived Organizational Support, Job Satisfaction, and Performance. Journal of Business and Psychology, 29(2), 269-280. https://doi.org/10.1007/s10869-013-9312-y

Drummond, S., \& Brough, P. (2016). Proactive coping and preventing coping: Evidence for two distinct constructs? Personality and Individual Differences, 92(2016), 123-127. http://dx.doi.org/10.1016/j.paid.2015.12.029

Dwivedi, A., Rastogi, R. (2017). Proactive coping, time perspective and life satisfaction: a study on emerging adulthood. Journal of Health Management, 19(2), 264-274. https://doi.org/10.1177/0972063417699689

Erana-Rojas, I.E., Lopez, M. (2021). Meaningful dialogue with students amid the pandemic. Medical Education. https://doi.org/10.1111/medu.14490

Fernández-Abascal, E.G., Chóliz Montañés, M., Palmero Cantero, F., \& Martínez Sánchez, F. (1997). Cuaderno de prácticas de motivación y emoción. España: Pirámide.

Folkman, S., Lazarus, R.S. (1980). An Analysis of Coping in a Middle-Aged Community Sample. Journal of Health and Social Behavior, 21(3), 219-239. https://www.jstor.org/stable/2136617

Folkman, S., Lazarus, R.S., Dunkel-Schetter, C., DeLongis, A., Gruen, R.J. (1986). Dynamics of a Stressful Encounter: Cognitive Appraisal, Coping, and Encounter Outcomes. Journal of Personality and Social Psychology, 50(5), 992-1003. https://doi.org/10.1037/0022-3514.50.5.992

Foster, M., Mulroy, T., \& Carver, M. (2020). Exploring Coping Strategies of Transfer Students Joining Universities From Colleges. Student Success, 11(1). https://doi.org/10.5204/ssj.v11i2.1617 
Greenglass, E., Schwarzer, R., Jakubiec, D., Fiksenbaum, L., \& Taubert, S. (1999, July). The proactive coping inventory (PCI): A multidimensional research instrument. In $20^{\text {th }}$ International Conference of the Stress and Anxiety Research Society (STAR), Cracow, Poland (Vol. 12, p. 14).

Guzman, A. B. D., \& Choi, K. O. (2013). The relations of employability skills to career adaptability among technical school students. Journal of Vocational Behavior, 82(3), 199-207. https://doi.org/10.1016/j.jvb.2013.01.009

Hernández, R., Fernández, C., \& Baptista, P. (2006). Metodología de la Investigación. Mexico: McGrawHill.

Kivunja, C. (2014). Teaching Students to Learn and to Work Well with $21^{\text {st }}$ Century Skills: Unpacking the Career and Life Skills Domain of the New Learning Paradigm. International Journal of Higher Education, 4(1). https://doi.org/10.5430/ijhe.v4n1p1

Kim, K., \& Lee, Y. M. (2018). Understanding uncertainty in medicine: concepts and implications in medical education. Korean journal of medical education, 30(3), 181-188. https://doi.org/10.3946/kjme.2018.92

Llisterri Caro, J. L. (2020). La maldita pandemia: una oportunidad para la Atención Primaria de Salud. SEMERGEN, 46(3), 149-150. https://doi.org/10.1016/j.semerg.2020.03.001

Mansfield, C. F., Beltman, S., Broadley, T., \& Weatherby-Fell, N. (2016). Building resilience in teacher education: An evidenced informed framework. Teaching and Teacher Education, 54, 77-87. http://dx.doi.org/10.1016/j.tate.2015.11.016

Méndez Reguera, A., \& Lopez, M. (2020) Coronabunker: Let's just not talk about 'it'. Medical Education, 54(11), 1053-1054. DOI: 10.1111/medu.14306

Nieto, A., \& Lopez, M. (2020). One giant leap for mankind: The experience of studying medicine through the pandemic. MedEdPublish, 9. https://doi.org/10.15694/mep.2020.000274.1

Olivares, S. L., Adame, E., Treviño, J. I., López, M. V., \& Turrubiates, M. L. (2019). Action learning: challenges that impact employability skills. Higher Education, Skills and Work-Based Learning, 10(1), 203-216. https://doi.org/10.1108/heswbl-07-2019-0097

Olivares, S.L., López, M.V., Valdez-García, J.E. (2018). Aprendizaje Basado en Retos. Educación Médica, 19(3), 230-237. https://doi.org/10.1016/j.edumed.2017.10.001

Palacios Cruz, M., Santos, E., Velázquez Cervantes, M.A., \& León Juárez, M. (2020). COVID-19, una emergencia de salud pública mundial. Revista Clínica Española. https://doi.org/10.1016/j.rce.2020.03.001

Parker, W.M., Donato, K.M., Cardone, K. E., \& Cerulli, J. (2017). Experiential Education Builds Student Self-Confidence in Delivering Medication Therapy Management. Pharmacy, 5(39), 2-11. DOI: 10.3390/pharmacy5030039.

Peña-Martínez, H., Lopez, M. (2021). The COVID-19 Pandemic: The 2020s Cataclysm for Traditional Medical Education. Educacion Medica. DOI: 10.1016/j.edumed.2020.11.006

Peña-Otero, D., Díaz-Pérez, D., Rosa-Carrillo, D. D. L., \& Bello-Dronda, S. (2020). Are we ready for the new coronavirus? Archivos De Bronconeumología, 56(4), 195-196. https://doi.org/10.1016/j.arbr.2020.02.003

Pidgeon, A. M., \& Pickett, L. (2017). Examining the differences between university students' levels of resilience on mindfulness, psychological distress and coping strategies. European Scientific Journal, 103-113. http://eujournal.org/index.php/esj/article/view/9246

Poh-Sun, G., Sandars, J. (2020). A vision of the use of technology in medical education after the COVID-19 pandemic. MedEdPublish, 9(1), 49. https://doi.org/10.15694/mep.2020.000049.1

Roesch, S. C., Aldridge, A. A., Huff, T. L., Langner, K., Villodas, F., \& Bradshaw, K. (2009). On the dimensionality of the Proactive Coping Inventory: 7, 5, 3 factors? Anxiety, Stress \& Coping, 22(3), 327-339. https://doi.org/10.1080/10615800802082304 
Rose, S. (2020). Medical Student Education in the Time of COVID-19. JAMA, 323(21), 2131. https://doi.org/10.1001/jama.2020.5227

Schiller, J., Stansfield, R.B., Belmonte, D., Purkiss, J., Reddy, R.M., House, J.B., \& Santen, S. (2018) Medical Students' Use of Different Coping Strategies and Relationship With Academic Performance in Preclinical and Clinical Years. Teaching and Learning in Medicine, 30(1), 15-21. DOI: 10.1080/10401334.2017.1347046

Steinhardt, M., Dolbier, C. (2008). Evaluation of a resilience intervention to enhance coping strategies and protective factors and decrease symptomatology. Journal of American College Health, 56(4), 445-453. 10.3200/JACH.56.44.445-454

Trilla, A. (2020). Un mundo, una salud: la epidemia por el nuevo coronavirus COVID-19. Medicina Clínica, 154(5), 175-177. https://doi.org/10.1016/j.medcli.2020.02.002

Valdez-García, J.E, López, M., Jiménez, M.A., Díaz, J.A., Dávila, J., \& Olivares, S.L. (2020). Me preparo para ayudar: respuesta de las escuelas de medicina y ciencias de la salud ante COVID-19. Investigación en Educación Médica. https://doi.org/10.22201/facmed.20075057e.2020.35.20230

Vogt, P. (2007). Quantitative research methods for professionals. Boston, MA: Pearson/Allyn and Bacon.

WHO. (2020, March 11). WHO Director-General's opening remarks at the media briefing on COVID-19. World Health Organization. https://www.who.int/dg/speeches/detail/who-directorgeneral-s-opening-remarks-at-the-media-briefing-on-covid-19---11-march-2020. 